\title{
A Review of the Literature on Corporal Punishment in The Bahamas, with an Emphasis on its Use in Schools
}

\author{
William J. Fielding (iD https://orcid.org/0000-0001-5433-9673 \\ Institutional Strengthening \& Accreditation \\ Virginia Ballance (D) https://orcid.org/0000-0003-1067-8205 \\ University Libraries \\ University of The Bahamas \\ https://doi.org/10.15362/ijbs.v26i0.353
}

\begin{abstract}
This review of the literature concerning corporal punishment arising from The Bahamas enables us to identify several strands: (1) corporal punishment is an historically accepted method of controlling children which only recently has been called into question; (2) school teachers have typically seen corporal punishment as a useful classroom management tool; (3) there has been unease about its use in schools which has resulted in its regulation; (4) more recently, there has been evidence of the awareness of the long-term negative effects of corporal punishment; and (5) the rise of social media has made corporal punishment and its potential abuses visible to a wider audience. These strands appear to have woven together to move the country in a direction of outlawing corporal punishment, at least in schools.
\end{abstract}

\section{Introduction}

At the global level, there is an association between peace and innovation, as demonstrated in Figure 1. Countries with a lower Peace Index are more peaceful, both in terms of internal violence, and threats from outside of the country. Countries with a higher Global Innovation Index are those which are more innovative and have higher research outputs. Those countries which have the highest levels of peace also have the most innovation, which suggests that innovation, which is ultimately the driver of the economy and prosperity, thrives in a peaceful society. Those counties which have outlawed corporal punishment have the higher peace indices, which in turn, demonstrates that violence, in the form of corporal punishment, is associated with peace. Thus, the administration of corporal punishment is not only associated with the level of peace enjoyed by a country, but corporal punishment is therefore linked with innovation, and the greater prosperity of the country (see Table 1).

Table 1

Mean Global Innovation Indexes of countries where corporal punishment is and is not legal.

\begin{tabular}{lcc}
\hline & \multicolumn{2}{c}{ Corporal Punishment } \\
\hline Global Innovation Index 2019 & Legal & Outlawed \\
\hline Mean & 32.2 & 37.9 \\
SE & 2.02 & 1.24 \\
\hline
\end{tabular}

Note: List of countries where corporal punishment is outlawed taken from Gershoff (2017). 
Figure 1

Association between Global Innovation Index and the Global Peace Index in 2019.

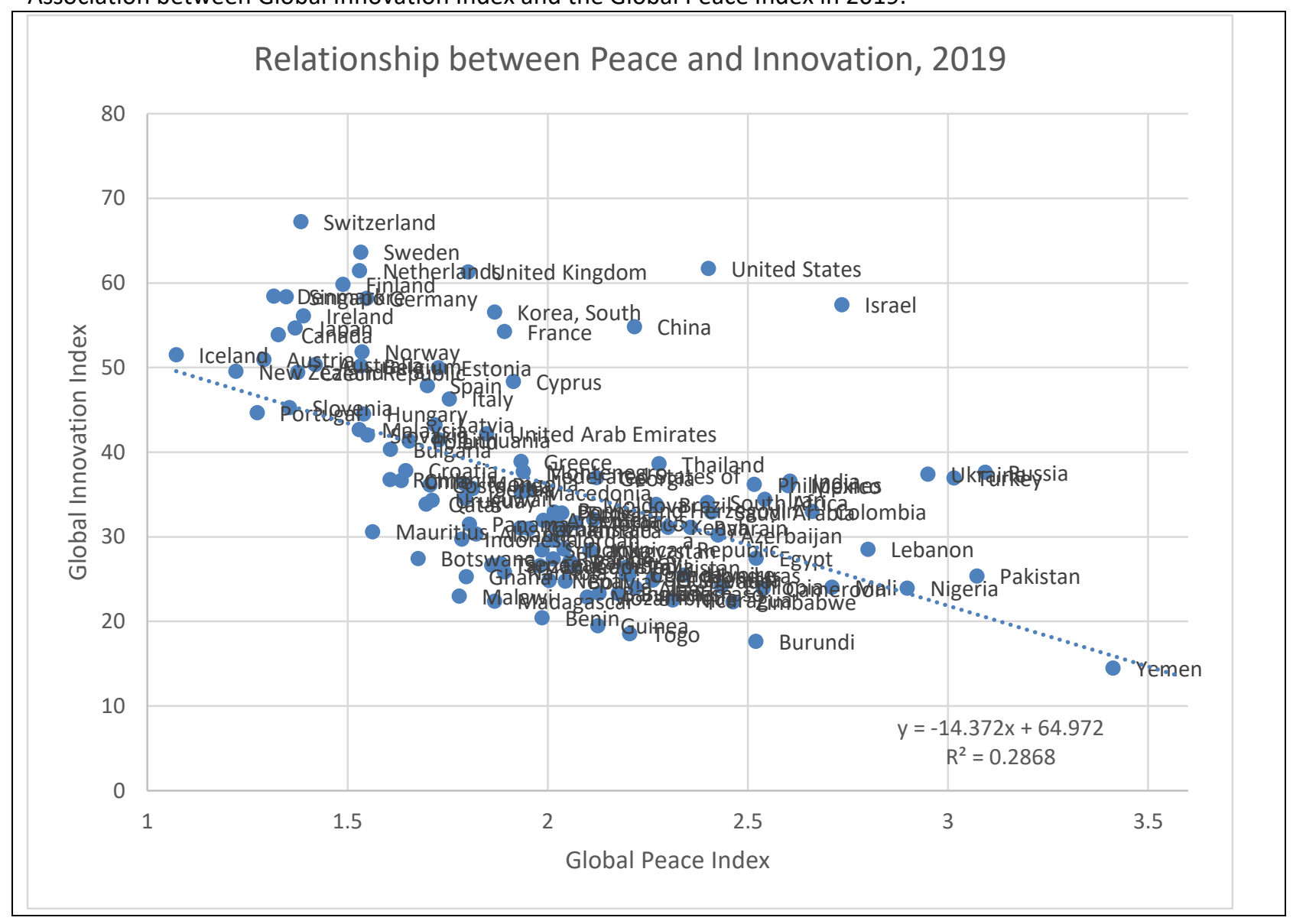

Notwithstanding these large-scale associations which suggest that corporal punishment has high-level implications, corporal punishment remains legally permitted in 69 countries (35\%), placing The Bahamas in the minority group of world nations (Global Initiative to End All Corporal Punishment of Children, 2018). The Bahamas signed the United Nations Convention on the Rights of the Child (1989) in 1991, and so it is expected to harmonize its laws to align with the obligations accepted by signing the treaty. However, as with other countries in the Caribbean region as a whole, The Bahamas has been slow to outlaw corporal punishment even though it is increasingly accepted that corporal punishment is a driver of the violence seen within Caribbean communities (Landon et al., 2017). Therefore, the purpose of this review paper is to help us appreciate the deep roots of corporal punishment within Bahamian society.

The 2014 Latin America Public Opinion Project carried out by Vanderbilt University provides a useful recent social context in which to read the Bahamian literature on corporal punishment. Many respondents were insistent that corporal punishment was always necessary or most often to discipline children (Table 2). 
Table 2

The necessity of parents to use corporal punishment on their children

\begin{tabular}{ll}
\hline & $\%$ \\
\hline Always & 10.2 \\
Most Often & 10.7 \\
Sometimes & 57.5 \\
Almost Never & 8.1 \\
Never & 13.5 \\
\hline N & 3316 \\
\hline Note: Derived from: Vanderbilt University (2014)
\end{tabular}

Respondents from lower income households were more likely than those who came from higher income homes to feel that corporal punishment is necessary to punish children (Table 3).

The study also indicated that older respondents were more likely than younger respondents to feel that corporal punishment is necessary to discipline a child (Table 4). This finding is useful to recall as we note a change in attitudes toward corporal punishment in the more recent literature.

Table 3

Relationship between household income and respondents' attitudes towards corporal punishment.

\begin{tabular}{|c|c|c|c|c|c|c|}
\hline \multirow{2}{*}{$\begin{array}{l}\text { Monthly household income } \\
\$\end{array}$} & \multicolumn{5}{|c|}{ Necessary to Use Physical Discipline with Children } & \multirow{2}{*}{$N$} \\
\hline & Always & Most Often & Sometimes & Almost Never & Never & \\
\hline$\$ 1000$ or less & $9.5 \%$ & $9.0 \%$ & $56.8 \%$ & $12.0 \%$ & $12.8 \%$ & 400 \\
\hline$\$ 1001-2000$ & $4.0 \%$ & $7.8 \%$ & $69.5 \%$ & $6.6 \%$ & $12.1 \%$ & 603 \\
\hline$\$ 2001-3400$ & $5.2 \%$ & $6.0 \%$ & $54.6 \%$ & $10.5 \%$ & $23.8 \%$ & 601 \\
\hline$\$ 3401-4800$ & $4.7 \%$ & $6.3 \%$ & $51.6 \%$ & $12.5 \%$ & $25.0 \%$ & 128 \\
\hline$\$ 4801$ or more & $1.9 \%$ & $11.4 \%$ & $60.0 \%$ & $13.3 \%$ & $13.3 \%$ & 105 \\
\hline
\end{tabular}

Note: Derived from: Vanderbilt University (2014)

Table 4

Relationship between the age of respondents and attitude towards corporal punishment.

\begin{tabular}{|c|c|c|c|c|c|c|}
\hline \multirow[b]{2}{*}{ Age group } & \multicolumn{5}{|c|}{ Necessary to Use Physical Discipline with Children } & \multirow[b]{2}{*}{$N=$} \\
\hline & Always & Most Often & Sometimes & Almost Never & Never & \\
\hline $18-19$ & $7.6 \%$ & $9.2 \%$ & $55.7 \%$ & $10.7 \%$ & $16.8 \%$ & 131 \\
\hline $20-29$ & $6.5 \%$ & $6.5 \%$ & $63.3 \%$ & $9.4 \%$ & $14.2 \%$ & 921 \\
\hline $30-39$ & $5.1 \%$ & $6.1 \%$ & $65.0 \%$ & $8.6 \%$ & $15.2 \%$ & 742 \\
\hline $40-49$ & $3.9 \%$ & $9.1 \%$ & $59.7 \%$ & $9.3 \%$ & $18 \%$ & 635 \\
\hline $50-59$ & $7.1 \%$ & $6.3 \%$ & $59.1 \%$ & $12.2 \%$ & $15.2 \%$ & 394 \\
\hline $60-69$ & $9.5 \%$ & $6.8 \%$ & $67.1 \%$ & $6.3 \%$ & $10.4 \%$ & 222 \\
\hline $70+$ & $10.6 \%$ & $5.3 \%$ & $65.5 \%$ & $6.2 \%$ & $12.4 \%$ & 113 \\
\hline
\end{tabular}

Note: Derived from: Vanderbilt University (2014)

This age-related attitude is reflected in the fact that the level of education of the respondent's mother was associated with the respondent's attitude towards the use of corporal punishment (Table 5). We should note that the modal level of education is secondary school (which was also evident in the 2010 Census, Bahamas Department of Statistics, 2012), and so the attitudes associated with this level of education will 
dominate those of society as a whole. Consequently, the finding that about one in eight of mothers with secondary education think that is it necessary to use physical discipline on a child is important, particularly as it is mothers who are those primarily responsible for administering corporal punishment (Fielding et al., 2015).

Table 5

Association between educational level of mother and attitude towards corporal punishment.

\begin{tabular}{|c|c|c|c|c|c|c|}
\hline \multirow[b]{2}{*}{ Education Level of Mother } & \multicolumn{5}{|c|}{ Necessary to Use Physical Discipline with Children } & \multirow{2}{*}{$N$} \\
\hline & Always & Most Often & Sometimes & Almost Never & Never & \\
\hline None & $4.8 \%$ & $8.6 \%$ & $67.6 \%$ & $8.6 \%$ & $10.5 \%$ & 105 \\
\hline Primary incomplete & $13.9 \%$ & $6.3 \%$ & $67.1 \%$ & $8.9 \%$ & $3.8 \%$ & 79 \\
\hline Primary complete & $2.8 \%$ & $7.5 \%$ & $74.0 \%$ & $11.0 \%$ & $4.7 \%$ & 254 \\
\hline Secondary incomplete & $4.6 \%$ & $5.7 \%$ & $74.9 \%$ & $7.9 \%$ & $6.8 \%$ & 367 \\
\hline Secondary complete & $4.8 \%$ & $6.7 \%$ & $57.4 \%$ & $10.6 \%$ & $20.5 \%$ & 1222 \\
\hline $\begin{array}{l}\text { Technical school/Associate degree } \\
\text { incomplete }\end{array}$ & $3.6 \%$ & $7.2 \%$ & $59.0 \%$ & $8.4 \%$ & $21.7 \%$ & 83 \\
\hline $\begin{array}{l}\text { Technical school/Associate degree } \\
\text { complete }\end{array}$ & $3.2 \%$ & $6.4 \%$ & $55.1 \%$ & $7.1 \%$ & $28.2 \%$ & 156 \\
\hline University incomplete & $5.1 \%$ & $8.5 \%$ & $55.9 \%$ & $16.9 \%$ & $13.6 \%$ & 59 \\
\hline University complete & $2.4 \%$ & $3.9 \%$ & $57.5 \%$ & $18.1 \%$ & $18.1 \%$ & 127 \\
\hline
\end{tabular}

Note: Derived from: Vanderbilt University (2014)

Identification with a religious community also influences attitudes towards corporal punishment (Table 6). This finding is also important when we read of the justification for using corporal punishment.

Table 6

Necessity of using corporal punishment on children by religion of respondent.

\begin{tabular}{|c|c|c|c|c|c|c|}
\hline \multirow[b]{2}{*}{ Religion } & \multicolumn{5}{|c|}{ Necessary to Use Physical Discipline with Children } & \multirow{2}{*}{$N$} \\
\hline & Always & Most Often & Sometimes & Almost Never & Never & \\
\hline $\begin{array}{l}\text { Church of the Latter-Day Saints } \\
\text { (Mormon) }\end{array}$ & $20 \%$ & $20 \%$ & $60.0 \%$ & $0 \%$ & $0.0 \%$ & 5 \\
\hline Jehovah's Witness & $9.1 \%$ & $6.1 \%$ & $70.7 \%$ & $6.1 \%$ & $8.1 \%$ & 99 \\
\hline $\begin{array}{l}\text { Agnostic or Atheist (Does not } \\
\text { believe in God) }\end{array}$ & $7.7 \%$ & $7.7 \%$ & $38.5 \%$ & $15.4 \%$ & $30.8 \%$ & 13 \\
\hline $\begin{array}{l}\text { Protestant, Mainline Protestant } \\
\text { or Protestant non-Evangelical }\end{array}$ & $7.2 \%$ & $7.6 \%$ & $63.1 \%$ & $10.4 \%$ & $11.8 \%$ & 821 \\
\hline Non-Christian Eastern Religion & $6.1 \%$ & $18.2 \%$ & $48.5 \%$ & $15.2 \%$ & $12.1 \%$ & 33 \\
\hline Evangelical and Protestant & $6 \%$ & $6.5 \%$ & $68.8 \%$ & $8.2 \%$ & $10.5 \%$ & 1243 \\
\hline Catholic & $5.3 \%$ & $5.8 \%$ & $54.3 \%$ & $11.0 \%$ & $23.6 \%$ & 812 \\
\hline None & $4.9 \%$ & $7.8 \%$ & $61.8 \%$ & $6.9 \%$ & $18.6 \%$ & 102 \\
\hline Traditional or Native Religion & $1 \%$ & $8.2 \%$ & $67.3 \%$ & $10.2 \%$ & $13.3 \%$ & 98 \\
\hline
\end{tabular}

Note: Derived from: Vanderbilt University (2014) 
There is also an apparent mindset that more severe punishment of criminals will reduce crime. This attitude is also linked with an attitude of the need to use corporal punishment on children (Table 7). This provides a link, which is useful to note, when we appreciate the historical use of corporal punishment on criminals. However, these attitudes are contrary to research from
Jamaica which highlights the link between negative parenting practices, including corporal punishment and crime (Smith \& Mosby, 2003). It is probably in recognition of these prevailing attitudes within society that government officials are cautious when they speak publicly on corporal punishment (see, for example, Brown, 2019).

Table 7

Association of the need to use corporal punishment on children and to punish prisoners.

\begin{tabular}{|c|c|c|c|c|c|c|}
\hline \multirow[b]{2}{*}{ How to Reduce Crime } & \multicolumn{5}{|c|}{ Necessary to Use Physical Discipline with Children } & \multirow[b]{2}{*}{$N$} \\
\hline & Always & Most Often & Sometimes & Almost Never & Never & \\
\hline $\begin{array}{l}\text { Increase punishment of } \\
\text { criminals }\end{array}$ & $6.9 \%$ & $7.2 \%$ & $65.7 \%$ & $8.6 \%$ & $11.7 \%$ & 1984 \\
\hline Implement preventive measures & $6.6 \%$ & $6.8 \%$ & $61.0 \%$ & $10.4 \%$ & $15.3 \%$ & 518 \\
\hline Both & $4.2 \%$ & $6.8 \%$ & $57.0 \%$ & $10.6 \%$ & $21.4 \%$ & 790 \\
\hline
\end{tabular}

Note: Derived from: Vanderbilt University (2014)

In The Bahamas, there is a prevailing opinion that attitudes towards corporal punishment are associated with the country's history of slavery. The system of slavery allowed for extreme corporal punishment, and this punishment had most clearly persisted in the state-approved use of corporal punishment for convicts, and persisted beyond Independence (Curry \& Ulentin, 2019). It follows that corporal punishment, together with its most emphatic form, capital punishment, has a long history in the country. Lofquist (2010) has documented the use of capital punishment until the last execution in 2000. In that review, it is of interest to note not only the change in the victims who were executed, from slaves to citizens, but that half of all death sentences have occurred in the period of national independence, starting in 1967, compared with the period of more than 275 years between 1784-1966, demonstrating an ever-increasing reliance on the death penalty as the ultimate form of deterrence.
Corporal punishment, long associated with slavery, has been an enduring part of the treatment of criminals, when historically those who break rules are required to be punished (Curry \& Ulentin, 2019), rather than taught to be productive members of society. The current prevailing attitude in Bahamian society is that more severe punishments are required to deter criminal behaviour, rather than rehabilitation (Sutton \& Ruprah, 2017). The law of The Bahamas still allows the use of flogging of criminals. Of interest is that the current law regarding flogging of criminals was introduced in 1991 (Criminal Law (Measures) Act No. 12 of 1991, Ch. 101), and so it is a clear "Bahamian" response to law and order, rather than being a colonial residue.

Smith (1979) indicates that as in the home (Otterbein \& Otterbein, 1973) corporal punishment is thought to be necessary to train children at school: 
Personal conversations show that the use of corporal punishment is deeply engrained in Bahamian philosophy, since most Bahamians think that this is the most effective method of teaching obedience to children and getting them to respect authority. Discussions have proven that some Bahamian Educators advocate corporal punishment to maintain satisfactory academic performance and proper child training. Consequently, the Bahamian child associates teaching with the cane.

Stories told by certain Bahamian senior citizens disclose that about thirty or forty years ago the regular use of corporal punishment was the causes [sic] of much concern in certain Bahamian schools as teachers tried to instil knowledge into their students, with the cane. In the classroom, silence and submission seemed to be a part of the Golden Rule, and the competence of a principal was mainly assessed by his ability to control his students. At that time, there were fewer schools in New Providence, and experiences were presumably different from the present. But in the Out Islands' (the other Bahamian Islands) Head teachers held the monopoly on using the case, and discussions show that several principals abused their authority. Most offenders received public corporal punishment which in some cases was inflicted with severity. (Smith, 1979, p. 2)

This use of violence to train children continues to this day as demonstrated by Brennen et al. (2016) and Carroll et al. (2016). The continued use of violence to discipline children is one that is handed on from one generation to the next in the belief that it is the appropriate action to take. Corporal punishment of children is not only approved in The Bahamas but has a higher approval rating than in other Caribbean nations (Sutton \& Álvarez, 2016), which further demonstrates the tolerance society has of corporal punishment.

The religious justification for using corporal punishment was manifested in a newspaper article on corporal punishment which appeared in the Religion section of the Nassau Guardian (Minnis, 2008). However, this justification is typically based on a misquotation from the Book of Proverbs. "Spare the rod and spoil the child" comes from a satirical love poem, "Hudibras," first published in 1684 by Samuel Butler. The actual biblical quote, "whoever spares the rod hates the child, but whoever loves will apply discipline" (Proverbs 13:24), may have a purely theological interpretation which would not endorse violence (Popcak, n.d.). Christian groups which are almost exclusively biblically focused, tend to have stronger attitudes than those groups which do not, on the necessity of corporal punishment (Table 6).

Long studies of student teachers written in the 1970-80s can be found in the Bahamian Special Collection of University of The Bahamas. The emphasis on discipline in schools is summed up by Adderley in the 1970s, "discipline is the hall-mark [sic] of a truly successful school" (p. 1). The perceived association between rigorous discipline and learning was repeated by the Minister of Education in 1983, "there is no question that certain elements in our schools, have allowed discipline and learning to go to the dogs" (Cartwright, 1986). Smith, in 1979, offers this observation, "the Bahamian child associates teaching with the cane" (p. 2). However, he points out that "stories told by certain Bahamian senior citizens disclose that about thirty or forty years ago the regular use of corporal punishment was the cause of much concern in certain Bahamian schools as teachers tried to install knowledge into their students with the cane" (p. 2) 
What is of interest in these long studies is that those teachers who discussed corporal punishment did so not usually from a teaching perspective, but rather as to how it was or was not an aid to classroom management.

Smith's (1979) study on physical punishment is focused on its effects and perceptions of students and teachers, rather than considering alternative forms of discipline. His definition of corporal punishment is instructive, "the inflicition [sic] of physical pain by flogging a person in school with a switch or cane" (p. 4). An advantage of corporal punishment was that it was considered to instil "fear in students" (p. 30). Although $22 \%$ of students and $7 \%$ of teachers strongly agreed with that statement, $15 \%$ of students and 10\% of teachers strongly agreed with the statement that corporal punishment improved student behaviour. Of note was that $36 \%$ of students indicated that the use of corporal punishment caused them to worry and $28 \%$ thought that it caused them to lose their self-confidence. From Smith's 1979 study, we can appreciate the long standing fact that boys are more likely than girls to be beaten ( $70 \%$ of boys cf $59 \%$ of girls), a pattern more recently observed by Fielding (2016) and Johnson (2019). Barnett's 1979 study indicated that most teachers (72\%) disagreed that corporal punishment should be abolished, whereas $68 \%$ of students agreed that caning was humiliating. This is consistent with the later findings of Knowles (1999) on young Bahamian children, namely that boys abused through excessive punishment had lower self-esteem than those who suffered less punishment.

What is noteworthy is that the installing "fear" in students in a learning environment is considered to be useful. There appears to be little concern that fear might inhibit the ability of pupils to learn. There also seems to be little awareness as to any long-lasting illeffects of hitting a child with a cane or the risk of abuse which such an action put the child. Consequently, it can be appreciated that the evidence from the 1970s was suggesting that caning was humiliating, but apparently this was considered acceptable to teachers who may not have considered the longer-term aspects of the punishment. Research by Allen et al. (2017) has highlighted the long-term destructive aspects of hurt (humiliation) and shame, which can, of course, arise from being a victim of corporal punishment.

Smith's conclusions indicate that corporal punishment had effects on the pupils which are not consistent with the purpose of a school education, and overall, "the disadvantages outnumber the advantages" (1979, p. 2):

The sample of the study did suggest that there are certain advantages and disadvantages of using corporal punishment in senior high schools. It would appear as though the disadvantages outnumber the advantages, for while student control and motivation to learn seem to be advantages, apparent disadvantages are dislike of school, disobedience toward teachers, vandalism, worry, rebellion and loss of self-respect.

The study did not demonstrate that corporal punishment instils a great deal of fear, nor did it confirm that students regard such penalty as sign of the inflictor's hate or teacher incompetence. It did, however, reveal that Tenth Graders do not favour corporal punishment and would like to see it taken out of the senior high schools, even though it is only used sometimes.

The suggestion seems to be that teachers must find another way of controlling students and motivating them to learn. But corporal punishment needs to be used then the inflictor should be conscious of the risk involved in using it. In the light of this fact, corporal punishment should be 
administered by persons in authority, with care and justice and in the presence of a witness. (Smith, 1979, pp. 87-88)

In parallel, as it were, to the concerns of classroom management, the research indicates an interest in the policies and procedures associated with corporal punishment. This indicates that the punishment needed to be regulated. This then suggests that there was a concern that corporal punishment had the potential to inflict unmerited harm on the pupils, possibly as a result of its overzealous "infliction" by teachers.

Moxey (1980) examined perceptions of school administrators and teachers towards corporal punishment. At that time, corporal punishment was used in primary schools as well as higher level schools. He points out that in the 1936 Board of Education Act as well as the 1975 Education Act there were no guidelines as to the methods which could be used to administer corporal punishment by Head Teachers. Moxey references two interviews with senior teachers and one suggests that corporal punishment should only be used in primary schools and another who thought "punishment in all its forms should be used" as "some students understand nothing other that [sic] physical punishment" (1980, p. 4). However, both these interviewees agreed that physical punishment should be the method of "last resort" (1980, p. 5). Moxey also makes the point that "the home and the school have to work as a unified body concerning this matter" [elimination of physical punishment from public schools]. Moxey's concern was echoed by Cartwright (1986) whose study of teachers indicated that $92 \%$ of them agreed that student behaviour depended on the home environment from which they emerged. In 2008, the importance of the home environment on academic achievement was demonstrated (Collie-Patterson, 2008), which highlights the continuum between the home and school environments. Johnson (2016) examined the wider implications between violence in the home and in the classroom, both as it relates to the teacher and the pupil. Both teacher and pupil bring their domestic experiences into the classroom, and violence from home can manifest itself in the classroom, albeit in modified ways.

Barnett noted that most teachers were against corporal punishment being abolished (71.6\%). He quotes an earlier study by Shirley Stubbs in 1977 which found that teachers use corporal punishment because of its convenience and that "they were reluctant to use methods [that] required extra efforts on their part" (1979, p. 6). Moxey (1980) found that most of those in his study, 53\% of teachers and $69 \%$ of administrators, approved of physical punishment and overall, $75 \%$ thought that the cane should be used. Less than half, $21 \%$ of teachers thought that canning was effective. Rolle's 1982 study was apparently carried out at a time when, quoting a Ministry of Education official, there was "rampant lack of discipline" in the Bahamian schools (p. 3). He found that suspension was then more popular amongst administrators than caning. He also seemed to suggest that the increased use of nonphysical punishment was associated with the discipline problems. However, as has been shown more recently (Johnson, 2019), suspension can heighten the risk that suspended pupils may drop out of school and become recruited to the criminal population. This would suggest that no child be punished in a way which might increase their risk of engaging in criminal activity.

As noted by Moxey (1980), although corporal punishment was permitted in schools, there appeared to be no guidance as to how it should be administered. The death of a student in 2000, resulting from corporal punishment (Mitchell, 2000), resulted in the revision of the Code of Student Conduct (Bahamas Ministry of Education, 1992) 
which in turn resulted in the Safe Schools Protocol. The Code of Student Conduct described the students' actions which were unacceptable, and what the maximum and minimum disciplinary action would be associated with each type of misconduct. Of note, this document did not indicate which offences warranted corporal punishment, other than, "caning will be administered by the principal or a person/persons designated by the principal in an attempt to comply with the responsibility for controlling and disciplining students assigned to the school" (p. 8). About the same time, it became illegal to use corporal punishment on children aged five or under in pre-schools (Early Childhood Care Act [2004] and Early Childhood Care [National Standards] Regulations 2015 [Bahamas] and the Residential Care Establishments Act [2004]). This then, would to be a first step to outlawing corporal punishment in schools.

The long-standing use of corporal punishment in schools was revisited in the Department of Education's Safe Schools Protocol, revised in 2009. The guidelines for the use of corporal punishment are given in Table 8.

\section{Table 8}

Guidelines for the use of corporal punishment as stated in the 2009 edition of the Safe Schools Protocol of the Department of Education.

\section{CORPORAL PUNISHMENT}

Corporal Punishment, which is defined as physically handling a student in any way to inflict punishment, should only be administered by the Principal or Administrator.

Staff may, in dealing with disruptive students, use reasonable and appropriate physical intervention or force as necessary for the following purposes:

To restrain a student from an act of wrong- doing.

To quell a disturbance threatening physical injury to others.
To obtain possession of weapons or other dangerous objects upon a student, or within the control of a student.

For the purpose of self-defence.

For the protection of persons or property.

For the preservation of order.

ADMINISTERING CORPORAL PUNISHMENT

I. Corporal Punishment should be limited to certain highly restricted circumstances (e.g. bullying, fighting, obscene language, threats, gross insubordination);

II. It may only be inflicted in the case of continued or grave circumstances and after a full inquiry has been carried out, and NOT IN THE PRESENCE OF OTHER STUDENTS. Female students should be punished by a female administrator, and a male by a male administrator, wherever possible.

III. Corporal Punishment must be accurately documented in ALL cases (within the same day);

IV. It should relate to the offence, and be adapted to fit the individual child and should be preceded by a conference with parents and students, where necessary.

Comments in the press at the time of Shawn Evans' death in 2000 focused on the need for corporal punishment to impose discipline and the fact that the use of corporal punishment was widespread and administered with the tacit approval of the Ministry of Education (Mitchell, 2000). The outcry against the possibility of the teacher facing life imprisonment closed schools for three days. Comments in the report by Mitchell suggested a similar teacher mindset to that reported in the literature of the 1970s.

The impact of the Safe Schools Protocol was assessed by The College of The Bahamas in 2012 and published in Johnson (2016). It indicated that its implementation had reduced the percentage of teachers who used corporal punishment and that the majority of teachers (77.5\%) thought that alternative forms of discipline were just as effective as using corporal punishment. The study also indicated that $21.1 \%$ of teachers thought that 
corporal punishment was the most effective way to maintain order in class. However, teachers were unwilling to give up the right to use corporal punishment as they felt that it was associated with their authority in the classroom. These attitudes aligned, to some extent, with their own use of corporal punishment at home, when $88.4 \%$ of teachers $\mathrm{did} /$ would use corporal punishment on their own children.

What is of interest in these more recent developments to regulate the use of corporal punishment is that an observation from Smith in 1979 seems to have been overlooked, namely that only $34 \%$ of teachers indicated that they thought "corporal punishment had helped them in teaching" and a minority of both students (49\%) and teachers (44\%) thought that corporal punishment improved student behaviour.

The use of corporal punishment is not confined to school. It also occurs in the home, being the disciplinary method of choice of parents (for example: Carroll et al., 2016). Therefore, while considering the use of corporal punishment in schools, its use outside of the educational setting cannot be overlooked. Further, we should be aware that the use of "corporal punishment" inflicted on children is part of an accepted part of the violence continuum, where physical punishment can be inflicted, usually on women, for not doing chores or being unfaithful (Nicolls et al, 2014; Sutton \& Álvarez, 2016). The end point of this continuum is violence associated with the home which can end in death, as illustrated by domestic related homicides being the fourth most common motive associated with homicides between 2010-2015 (Hanna, 2017, p. 5).

The widespread use of corporal punishment in the home has a long tradition in The Bahamas and is associated with religious beliefs (Otterbein \& Otterbein, 1973). As noted earlier, this may be associated with the misattribution of "Spare the rod and spoil the child" to the Book of Proverbs in the Bible, as well as a misunderstanding. However, as with the learning of gender stereotypes, we should not overlook the role of pastors in influencing the attitudes of parents, in particular mothers (Fielding \& Ballance, 2019). Corporal punishment is a cultural norm of The Bahamas and the Caribbean region (Ballance, 2008), which is still endorsed by most people (Sutton \& Alvarez, 2016). Brennen et al. (2016) and Carroll et al. (2016) demonstrate the continued use of corporal punishment to train children in The Bahamas and that its use can result in abuse of the child. Brennen et al.'s 2016 study also indicates that the level of violence considered as abuse in the Bahamian context is more in line with what would be termed grievous bodily harm elsewhere. Fielding et al. (2015) demonstrated that college students in The Bahamas were subject to more corporal punishment than their counterparts in the United States of America and this in turn was linked with Bahamian students having higher risks of exhibiting behaviours of concern when an adult, for example anger, which again points to the longer-term consequences of corporal punishment. The consequences of anger in the Bahamian context have been discussed by Bethel et al. (2015).

The longer-term and wider implications of exposure to violence have been indicated by Fielding (2016). Inmates at the Department of Correctional Services Facility at Fox Hill, typically emerge from more violent backgrounds that those of the general population, in terms of physical, emotional, and physical abuse. Further, some $25 \%$ of inmates had failed to complete school (Johnson, 2019), and Minnis et al. (2016) reported that about half of the inmates in their study were expelled from school. Globally, while it can be demonstrated that corporal punishment is associated with reduced 
innovation, Fielding \& Johnson (2019) found that being physically disciplined in high schools was associated with reduced level of university student creativity. This finding is consistent with Bahamian research which has linked exposure to corporal punishment, at home and a reduced ability to solve problems and reduced executive function (Roth et al., 2020). This research suggests that the use of corporal punishment is incompatible with the goals of education.

While the use of corporal punishment has been seen as a usual classroom management tool, today, the educational system has evolved into a two-track system, with some schools no longer using corporal punishment while others continue to do so. Therefore, it is possible to assess if corporal punishment has a beneficial effect on the results in national examinations. The data in Table 9 do not seem to support the idea that the use corporal punishment enhances student learning.

The deeply engrained attitude towards physical punishment as a means of changing behaviour is manifested in public opinion towards criminals. Many residents of The Bahamas feel that the best way to reduce crime is to increase the punishment of criminals (Fielding, 2016) and to make their time of imprisonment a part of the

Table 9

Percentage of students obtaining A-C passes in 2005 in BGCSE examinations.

\begin{tabular}{ccccc}
\hline & & \multicolumn{2}{c}{ Percentage of A-C grades } & $\chi^{2}$ test \\
High School & Corporal punishment & English Language & Mathematics & $p$ \\
\hline R. M. Bailey & Used & $16 \%$ & $14 \%$ & .32 \\
C. V. Bethel & Not used & $15 \%$ & $20 \%$ & .01 \\
\hline
\end{tabular}

Note: Derived from data from The Bahamas Ministry of Education.

\section{Media Reports}

The Tribune of the September 6, 2018 includes a report of a boy being beaten by a school administrator. Social media was used to share a photo of the bruises which the boy punishment rather than a time for rehabilitation (Ballance, 2019; Oenbring, 2019). The ever-increasing access to social media, and the proliferation of cameras, through smartphones, has resulted in the use of corporal punishment in schools becoming more public, even though it should take place in private. This has resulted in a number of cases being documented through social media and being re-reported in the traditional media.

When considering corporal punishment reports in the press, we should remember that it is typically going to be framed in a negative light. However, these reports' value is that they are illustrative of events which have made such an impression on those concerned as to involve the national media, and so takes the complaint beyond something which is shared on social media into the realm of more "official" news. This gives the complaint a legitimacy which might not occur to something shared only on social media platforms. The use of social media in reporting these events, can mean that the beating becomes public beyond the environments of the school. This can further add to the humiliation and shame of the victims. Below, we make reference to just a few recent reports. 
who recorded the punishment. The event was regarded as being in contravention of the guideline on using corporal punishment. An article of May 20,'2019 in The Tribune is an example of a social media post concerning a student injured as a result of corporal punishment being given prominence in the national news. The report elicited very strong opinions from those who did and did not support corporal punishment.

On June 3, 2019, an anonymous letter to the editor published in The Tribune was in support of corporal punishment. It represented the view that using a cane or belt to leave marks on a child is not abuse. As such it demonstrates the traditional view of corporal punishment without regard to the long-term risks associated with this type of punishment. This letter also confirms that a severe level of violence is required for the punishment to be considered "abuse", a finding also noted by Brennen et al. (2016).

An article published on June 4, 2017 in The Tribune indicated the willingness of church associations to bring their perspective to bear on the use (and possible abuse) of corporal punishment, so as to prevent a prosecution of a teacher for harming a child by beating a child. This suggests an attitude that the teacher is justified in using corporal punishment and that the law should protect the teacher and not the child. This may be a dim reflection of earlier times, when here was little protection for the victims of corporal punishment.

\section{Discussion}

There is a vast literature on corporal punishment from overseas (Gershoff, 2010). The consensus of that literature is that the negative aspects of corporal punishment outweighs the short-term change in undesirable behaviour which it typically elicits.

While it can be appreciated how The Bahamas has used corporal punishment in previous generations, its use was without the benefit of recent research which confirms the long-term deleterious effects on the victim, and indeed the wider society. The literature arising from The Bahamas is in overall agreement with the foreign research. Further, while estimates as to the use of corporal punishment in schools are limited, in a population of University students, $77 \%$ of males and $61 \%$ of females had been physically disciplined when at school (Fielding \& Johnson, 2019) which demonstrates that many students are at risk of the negative effects of corporal punishment. These long-term negative consequences of corporal punishment, which include: aggression,

anxiety/depression/disassociation, posttraumatic stress disorder, social problems, thought problems, social withdrawal (Lansford et al., 2002), threatening the longterm economic growth of the country and potentially contributing to the unacceptable level of violence in society (Elgar et al, 2018).

\section{Conclusion}

It is possible that the widespread use of corporal punishment, in homes and schools, has contributed to a lack of research on this topic in The Bahamas. Apart from Knowles, 1999, little thought seems to have been given about the long-term impact of corporal punishment. Since the start of the 20th century, the association of corporal punishment and its consequences have started to be researched in The Bahamas. The results of the Bahamian-focused research have been consistent with the extensive literature from overseas. While researchers have become increasingly aware of the deleterious effects of corporal punishment, the lack of a concerted and consistent public awareness campaign has resulted in society clinging to its unsubstantiated beliefs concerning corporal punishment. 


\section{Acknowledgement}

This paper arose from an invitation to the authors from Dr. Rodney Smith, President and CEO of University of The Bahamas, to provide information to a committee formed to advise the Minister of Education on corporal punishment.

\section{References}

Adderley, M. (2019, May 2). Teacher in beating video broke rules. The Tribune. http://www.tribune242.com/news/2019/ma y/03/teacher-beating-video-broke-rules/

Adderley, P. L. (197?). The problem of discipline in schools in New Providence [Manuscript].

Bahamas. Department of Education. (2009). Safe schools protocol: Manual for public schools. https://dloc.com/AA00068560/00001

Bahamas. Department of Statistics. (2012). 2010 census of population and housing. https://ufdc.ufl.edu/AA00077233/00001

Bahamas. Ministry of Education. (1992). Code of student conduct.

Ballance, V. C. F. (2008). Bahamas, Commonwealth of. In C. E. D'Avanzo (Ed.), Pocket guide to cultural health assessment (pp. 48-52). Mosby Elsevier.

Ballance, V. (2019). How do inmates spend their days? In W. Fielding, V. Ballance, P. Smith, A. Veyrat-Pontet, \& H. Sutton (Eds.), Our prisoners: A collection of papers arising from a 2016 survey of inmates at The Bahamas Department of Correctional Services facility at Fox Hill (pp. 149-59). Inter-American

Development Bank.

https://doi.org/10.18235/0001593

Barnett, B. W. (1979). A comparative study of the attitudes of teachers and students toward disciplinary procedures in selected schools in New Providence. [Unpublished B.Ed. thesis]. University of the West Indies, Nassau.

Bethell, K., Allen, D., \& Carroll, M. A. (2015). Using a supportive community group process to cope with the trauma of social fragmentation and promote resocialization in The Bahamas. Emergency Medicine: Open Access, 5(244), 2-6. https://doi.org/10.4172/2165-

7548.1000244

Brennen, S., Fielding, W. J., Carroll, M. C., McCants-Miller, J. C., Adderley, L., \& Thompson, M. A. (2016). A preliminary investigation of the prevalence of corporal punishment of children and selected cooccurring behaviours in households on New Providence, The Bahamas. In W. J. Fielding, V. C. F. Ballance, \& I. G. Strachan (Eds.), Violence in The Bahamas (pp. 63-78). University of The Bahamas.

Brown, K. (2019, June 12). Lloyd addresses corporal punishment in schools. The Nassau Guardian. 
https://thenassauguardian.com/2019/06/12/ lloyd-addresses-corporal-punishment-inschools/

Carroll, M. A., Fielding, W. J., Brennen, S., \& Hutcheson, S. P. (2016). Rearing violence: Violence toward children at home. In W. J. Fielding, V. C. F. Ballance, \& I. G. Strachan (Eds.), Violence in The Bahamas (pp. 31-62). University of The Bahamas.

Cartwright, A. R. (1986). A comparison of the causes of discipline problems perceived by a random sample of male and female government and private junior high school teachers in New Providence. [Unpublished B.Ed. thesis]. University of the West Indies, Nassau.

Collie-Patterson, J. M. (2008). The national average is D: Who is to blame? The College of The Bahamas Research Journal, 14; 28-37.

https://doi.org/10.15362/ijbs.v14i0.102

Corporal Punishment. (2019, June 3). Belts will leave a mark but that is not abuse [Letter to the Editor]. The Tribune. http://www.tribune242.com/news/2019/jun /03/belts-will-leave-mark-not-abuse/

Criminal Law (Measures) Act (1991) Bahamas (Ch. 101). http://laws.bahamas.gov.bs/cms/images/LE GISLATION/PRINCIPAL/1991/19910012/CriminalLawMeasuresAct_1.pdf

Curry, C., \& Ulentin, A. (2019). From punishment to rehabilitation: An historical overview of incarceration in The Bahamas. In W. Fielding, V. Ballance, P. Smith, A. Veyrat-Pontet, \& H. Sutton (Eds.) Our prisoners: A collection of papers arising from a 2016 survey of inmates at The Bahamas Department of Correctional Services facility at Fox Hill (pp. 3-20).
Inter-American Development Bank. https://doi.org/10.18235/0001593

Early Childhood Care Act (2004) and Early Childhood Care (National Standards) Regulations (2015) Bahamas. https://www.cavehill.uwi.edu//LAWLIBR ARY/getattachment/85786aa5-589b-48e884e1-78f986ce414a/EARLYCHILDHOOD-CARE-ACT.aspx

Elgar, F. J., Donnelly, P. D., Michaelson, V., Gariépy, G., Riehm, K. E., Walsh, S. D., \& Pickett, W. (2018). Corporal punishment bans and physical fighting in adolescents: An ecological study of 88 countries. BMJ open, 8(9), e021616. https://doi.org/10.1136/bmjopen-2018021616

Fielding, W. J. (2016). Violence in the life of an inmate prior to conviction. In W. J. Fielding, V. C. F. Ballance, \& I. G. Strachan (Eds.), Violence in The Bahamas (pp. 205-220). University of The Bahamas.

Fielding, W. J., \& Ballance, V. C. (2019). Learning gender-based attitudes in The Bahamas. International Journal of Bahamian Studies, 25, 1-15. https://doi.org/10.15362/ijbs.v25i0.339

Fielding, W. J., \& Johnson, P. (2019). Do teachers influence high school students' creativity? The experience of University students in The Bahamas. International Journal of Bahamian Studies, 25, 16-32. https://doi.org/10.15362/ijbs.v25i0.341

Fielding, W. J., Risley-Curtiss, C., \& Cronin, T. W. (2015). A cross-cultural comparison of interpersonal violence in the lives of college students from two colleges from The Bahamas and United States of America. International Journal of 
Bahamian Studies, 21(1), 38-56. https://doi.org/10.15362/ijbs.v21i1.230

Gershoff, E. T. (2010). More harm than good: A summary of scientific research on the intended and unintended effects of corporal punishment on children. Law \& Contemporary Problems, 73, 31-56. https://heinonline.org/HOL/LandingPage? handle $=$ hein.journals/lcp73\&div=18\&id $=$ \&page $=$

Gershoff, E. T., Goodman, G. S., MillerPerrin, C. L., Holden, G. W., Jackson, Y., \& Kazdin, A. E. (2018). The strength of the causal evidence against physical punishment of children and its implications for parents, psychologists, and policymakers. American Psychologist, 73(5), 626-638.

https://doi.org/10.1037/amp0000327

Global Initiative to End All Corporal

Punishment of Children. (2018, December). Country report for Bahamas. https://endcorporalpunishment.org/reportson-every-state-and-territory/bahamas/

Hanna, C. A. (2017). Solutions to the murder problem. National Anti-Drug Secretariat, Ministry of National Security. https://ufdc.ufl.edu/AA00061956/00001

Johnson, P. (2016). Violence in school. In W. J. Fielding, V. C. F. Ballance, \& I. G. Strachan (Eds.), Violence in The Bahamas (pp. 113-133). University of The Bahamas.

Johnson, P, (2019). Educational attainment and crime. In W. Fielding, V. Ballance, P. Smith, A. Veyrat-Pontet, \& H. Sutton (Eds.) Our prisoners: A collection of papers arising from a 2016 survey of inmates at The Bahamas Department of Correctional Services facility at Fox Hill (pp. 77-87). Inter-American Development Bank. https://doi.org/10.18235/0001593

Knowles, L. A. M. (1999). Impact of physical abuse on the psychological and behavioural state of institutionalized children in The Bahamas and Jamaica [Unpublished doctoral dissertation]. University of the West Indies, Mona, Jamaica. http://uwispace.sta.uwi.edu/ dspace/handle/2139/2346

Landon, B. G., Waechter, R., Wolfe, R., \& Orlando, L. (2017). Corporal punishment and physical discipline in the Caribbean: Human rights and cultural practices. Caribbean Journal of Psychology, 9(1). https://www.researchgate.net/profile/Barba ra_Landon/publication/331207188_Corpor al_Punishment_and_Physical_Discipline_i n_the_Caribbean_Human_rights_and_cult ural_practices/links/5c6c160692851c1c9de c4637/Corporal-Punishment-and-PhysicalDiscipline-in-the-Caribbean-Humanrights-and-cultural-practices.pdf

Lansford, J. E., Dodge, K. A., Pettit, G. S., Bates, J. E., Crozier, J., \& Kaplow, J. (2002). A 12-year prospective study of the long-term effects of early child physical maltreatment on psychological, behavioral, and academic problems in adolescence. Archives of Pediatrics \& Adolescent Medicine, 156(8), 824-830. https://doi.org/10.1001/archpedi.156.8.824

Lofquist, W. S. (2010). Identifying the condemned: Reconstructing and analyzing the history of executions in The Bahamas. International Journal of Bahamian Studies, 16, 19-34. https://doi.org/10.15362/ijbs.v16i0.125

Minnis, J., Symonette, E., Stevenson, M., Pintard-Newry, Y., \& Gibson, T. (2016). Who is in prison? In W. J. Fielding, V. C. 
F. Ballance, \& I. G. Strachan (Eds.), Violence in The Bahamas (pp. 181-204).

Nassau: University of The Bahamas.

Minnis, K. (2008, August 21). Is sparing the rod spoiling the child? Nassau Guardian, p. REL1.

Moxey, E. G. (1980). An investigation into administrators' and teachers' perception of the use of punishment in junior high schools in New Providence. [Unpublished B.Ed. thesis]. University of the West Indies, Nassau.

Nicolls, D., Russell-Smith, C., DeanPatterson, S., Deveaux-Stuart, L. D., Gibson-Mobley, I., Williams, E. J, PinderDarling, A., \& Fielding, W. J. (2014). Attitudes of high school students regarding intimate relationships and gender norms in New Providence, The Bahamas. International Journal of Bahamian Studies, 20(1), 38-51. https://doi.org/10.15362/ijbs.v20i1.225

Oenbring, R. A. (2019). Dey wan to convert Her Majesty Prison into da Ritz Carlton: A corpus-linguistic/content analysis of Bahamian newspaper and web-forum discourse on prisons. In W. Fielding, V. Ballance, P. Smith, A. Veyrat-Pontet, \& H. Sutton (Eds.), Our prisoners: A collection of papers arising from a 2016 survey of inmates at The Bahamas Department of Correctional Services facility at Fox Hill (pp. 21-32). Inter-American Development Bank. https://doi.org/10.18235/0001593

Otterbein, C. S., \& Otterbein, K. F. (1973). Believers and beaters: A case study of supernatural beliefs and child rearing in the Bahama Islands. American Anthropologist, 75(5), 1670-81. https://doi.org/10.1525/aa.1973.75.5.02a00 290
Popcak, G. K. (n.d.) Ten reasons I can't spank. A Catholic counselor's critical examination of corporal punishment. In D. $\mathrm{N}$. Bell, A Christian perspective on corporal punishment. https://nospank.net/popcak.htm

Residential Care Establishments Act (2004) Bahamas (Ch. 235A). http://laws.bahamas.gov.bs/cms/images/LE GISLATION/PRINCIPAL/2004/20040024/ResidentialCareEstablishmentsAct_1 .pdf

Rolle, R. R. (1982). Disciplinary practices in Bahamian public high schools.

[Unpublished B.Ed. thesis]. University of the West Indies, Nassau.

Roth, R. M., Abecassis, M., Isquith, P. K., \& Fielding, W. J. (2020, February 5-8). Corporal punishment in childhood is associated with self-rated executive functions in Bahamian college students. [Poster presentation]. International Neuropsychological Society Meeting, Denver, Colorado. https://www.theins.org/meetings/denver2020/

Smith, A. T. (1979). An investigation into the use of corporal punishment in senior high schools in New Providence and an examination of the advantages and disadvantages on tenth graders.

[Unpublished B.Ed. thesis]. University of the West Indies, Nassau.

Smith, D. E., \& Mosby, G. (2003). Jamaican child-rearing practices: The role of corporal punishment. Adolescence, 38(150), 369-381.

Sutton, H., \& Álvarez, L. (2016). How safe are Caribbean homes for women and children? Attitudes toward intimate partner violence and corporal punishment. 
Inter-American Development Bank. https://publications.iadb.org/en/publication /12617/how-safe-are-caribbean-homeswomen-and-children-attitudes-towardintimate-partner

Sutton, H., \& Ruprah, I. (2017). Restoring paradise in the Caribbean. Combatting violence with numbers. Inter-American Development Bank. https://publications.iadb.org/bitstream/han dle/11319/8262/Restoring-Paradise-in-theCaribbean-Combatting-Violence-WithNumbers.PDF? sequence $=1 \&$ isAllowed $=y$

United Nations Convention on the Rights of the Child. (1989). http://www.unhchr.ch/ $\mathrm{html} / \mathrm{menu} 3 / \mathrm{b} / \mathrm{k} 2 \mathrm{crc} . \mathrm{htm}$

Vanderbilt University. (2014). Latin America Public Opinion Project: The Bahamas. http://www.vanderbilt.edu/lapop/bahamas. php

\section{Reports of corporal punishment in the Bahamian press: A selection}

Adderley, M. (2018, May 11). Whipped, beaten and filmed for Facebook. The Tribune.

http://www.tribune242.com/news/2018/ma y/10/whipped-beaten-and-filmedfacebook/

Adderley, M. (2019, May 2). Teacher in beating video broke rules. The Tribune. http://www.tribune242.com/news/2019/ma y/03/teacher-beating-video-broke-rules/

Brown, K. (2019, June 12). Lloyd addresses corporal punishment in schools. The Nassau Guardian. https://thenassauguardian.com/2019/06/12/ lloyd-addresses-corporal-punishment-in- schools/

Corporal Punishment. (2019, June 3). Belts will leave a mark but that is not abuse [Letter to the Editor]. The Tribune. http://www.tribune242.com/news/2019/jun /03/belts-will-leave-mark-not-abuse/

Disturbed and Deeply Concerned. (2019, June $5)$. Beating children is our sport [Letter to the Editor]. The Tribune. http://www.tribune242.com/news/2019/jun /05/beating-children-our-sport/

Jones, R. (2019, June 13). Lloyd: Society must decide way forward on corporal punishment. Eyewitness News. https://ewnews.com/lloyd-society-mustdecide-way-forward-on-corporalpunishment

McKenzie, N. (2008, August 7). Baby-sitter fined for spanking infant. The Tribune. https://dloc.com/UF00084249/01094/3j?se arch=tribune

Minnis, K. (2008, August 21). Is sparing the rod spoiling the child? Nassau Guardian, p. REL1.

Rolle, R. (2019, December 16). Lloyd appalled by support for beating. The Tribune. http://www.tribune242.com /news/2019/dec/16/lloyd-appalled-supportbeating/

Rolle, R. (2018, March 5). School beatings must be very last resort. The Tribune. http://www.tribune242.com/news/2018/ma r/05/school-beatings-must-be-very-lastresort/

Russell, K. (2019, June 13). Social media danger must be addressed. The Tribune. http://www.tribune242.com/news/2019/jun /13/social-media-danger-must-be- 
addressed/

Scavella, N. (2016, November 2). Officer who struck fighting students 'was performing his duty'. The Tribune. http://www.tribune242.com/news/2016/no v/02/officer-who-struck-fighting-studentswas-performin/

Smith, S. (2018, October 26). Bahamians urged to move beyond corporal punishment. The Nassau Guardian. https://thenassauguardian.com/2018/10/26/ bahamas-urged-to-advance-beyondcorporal-punishment/

Strachan, M. (2019, June 17). Insight: The grey area of corporal punishment in schools may have made one administrator a sacrificial lamb. The Tribune. http://www.tribune242.com/news/2019/jun /17/insight-grey-area-corporal-punishmentschools-may-/

Study: Corporal punishment of children promoting culture of violence in region. (2011, November 18). The Nassau

\section{Guardian.}

https://thenassauguardian.com/2011/11/18/ study-corporal-punishment-of-childrenpromoting-culture-of-violence-in-region/

Turnquest, A. (2018, February 27). It's time to stop school beatings. The Tribune. http://www.tribune242.com/news/2018/feb /28/its-time-stop-school-beatings/
Turnquest, A. (2018, September 7). Student beating: Police investigate. The Tribune. http://www.tribune242.com/news/2018/sep /07/students-beating-police-investigate/

Turnquest, A. (2019, May 30). Father's fury as son comes home from school 'black and blue'. The Tribune. http://www.tribune242 .com/news/2019/may/30/fathers-fury-soncomes-home-school-black-and-blue/

Wallace, A. (2019, April 3). Schools have to get in the fight to protect our students. The Tribune. http://www.tribune242. com/news/2019/apr/03/alicia-wallacecolumn-schools-have-get-fight-prote/

Wells, R. (2019, April 4). Lloyd waiting on beating report. The Tribune. http://www.tribune242.com/news/2019/apr /04/lloyd-waiting-beating-report/

Wells, R. (2019, March 28). Out of order: Ministry probes teacher filmed beating students. The Tribune. http://www.tribune242.com/news/2019/ma $\mathrm{r} / 29 /$ out-order-ministry-probes-teacherfilmed-beating-s/

Wells, R. (2019, June 4). Bishop urges amicable solution to beating row. The Tribune. http://www.tribune242.com /news/2019/jun/04/bishop-urges-amicablesolution-beating-row/ 